\title{
Bone mineral density and its correlation with Vitamin D status in healthy adults of Manipur - A cross-sectional study \\ ${ }^{1}$ Dr. Sentitemsu Ao, ${ }^{2}$ Dr. Karthika. M, ${ }^{3}$ Dr. Temjensunep, ${ }^{4}$ Dr. Prakash Chandra Bhardwaj, ${ }^{5}$ Dr. Deisha Balari Rymbui, ${ }^{6} \mathrm{Dr}$. Bishu Debbarma \\ ${ }^{1}$ Medical Officer (MD Physiology), Department of Health \& Family Welfare, Kohima, Nagaland ${ }^{2}$ Assistant Professor, Department of Physiology, Saveetha Medical college, Thandalam, Chennai ${ }^{3}$ Medical Officer (MS Orthopedics) Department of Health \& Family Welfare, Kohima, Nagaland ${ }^{4}$ Medical Officer (MD Physiology), Department of Health Services, Manipur \\ ${ }^{5}$ Medical Officer, Department of Health \& Family Welfare, Meghalaya \\ ${ }^{6}$ Medical Officer (MD Physiology), Kherengbar Hospital, Agartala, Tripura
}

\begin{abstract}
The vitamin D level has an essential effect on bone mass and hypovitaminosis D adversely affects osteoblastic activity, bone remodeling, and hence bone density. Objective: The present study was conducted to determine the status of serum $25(\mathrm{OH}) \mathrm{D}$ and BMD of healthy adult men in Manipur and also to find out the relationship of 25(OH)D level with BMD. Methods: 100 Healthy adult males in Manipur in the age group 18-35years and $\geq 50$ years are included in the study The serum 25-OH vitamin D level is estimated by using an enzyme immunoassay (EIA) kit (IDS immune diagnostic systems, UK). The BMD of the lumbar spine was determined using enCORE - based X-ray bone densitometer which is based on the DEXA scan. Results: The present study revealed that the majority of subjects with insufficiency of $25(\mathrm{OH}) \mathrm{D}$ had low bone mass, whereas all the subjects with $25(\mathrm{OH}) \mathrm{D}$ deficiency had BMD readings consistent with osteopenia or osteoporosis in both the age groups. This study also showed a positive correlation between BMD and 25(OH)D in most subjects, particularly in the groups with insufficiency or deficiency of $25(\mathrm{OH}) \mathrm{D}$. Conclusion: In conclusion, the study shows a positive relationship between the serum $25(\mathrm{OH}) \mathrm{D}$ concentrations and BMD.
\end{abstract}

Keywords: Serum 25(OH)D; Bone mineral density (BMD).

\section{Introduction}

Ultraviolet radiation from the sun is the chief source of vitamin $\mathrm{D}$ in human, skin synthesis is limited by numerous factors, including pigmentation, time of day, the season of the year, latitude, age, and percentage of the skin surface area available for exposure. [1]

However, with increasing avoidance of sun exposure by the general population, they should ensure adequate dietary intake of vitamin D. The primary dietary sources of vitamin D are fortified dairy products, other dietary sources include egg yolks, fish oils and enriched cereal products. Vitamin D provided by the plant source is in the form of vitamin $\mathrm{D} 2$, whereas that provided by the animal source is in the form of vitamin D3, however quantities obtained from these sources are thought to be insufficient in achieving optimal serum vitamin D concentrations. [2]

Osteoporosis, the skeletal disease of bone thinning and compromised bone strength, characterized by bone fragility and increased susceptibility to fractures, especially of the spine and hip.5 Since bone loss occurs without symptoms, osteoporosis is a 'silent disease.' Osteoporosis in men is a major underestimated public

eISSN: 2523-6709

pISSN: 2523-6695

DOI: $10.31878 /$ ijcrpp.2020.41.02 health problem, increased life expectancy, advancing age -related illnesses has increased the prevalence furthermore. One out of three fractures seen in men over fifty is due to osteoporosis.

1Studies showed that men with osteoporotic fractures have higher mortality and morbidity when compared to women. This adds to the economic burden in developing countries especially India, where men are the only earning members in many families. [3]

The most specific screening test for vitamin D deficiency in an otherwise healthy individual is serum $25(\mathrm{OH}) \mathrm{D}$ level because it is the major circulating form of vitamin $\mathrm{D}$, also it has a half-life of 3 weeks, whereas $1,25(\mathrm{OH})_{2}$ $\mathrm{D}$ half-life is around 4 hours. This longer half-life of 25 $(\mathrm{OH}) \mathrm{D}$ makes it a very good indicator of vitamin D status. Although the normal range varies, levels of $25(\mathrm{OH}) \mathrm{D}$ $<37 \mathrm{nmol} / \mathrm{L}(<15 \mathrm{ng} / \mathrm{ml})$ are associated with increasing PTH levels and lower bone density; optimal vitamin D levels are $>80 \mathrm{nmol} / \mathrm{L}(>32 \mathrm{ng} / \mathrm{ml})$. [4]

Vitamin D deficiency causes parathyroid hormone secretion to increase which signals the kidneys to increase the production of $1,25(\mathrm{OH})_{2}$ D. This would make measurements of serum $1,25(\mathrm{OH})_{2} \mathrm{D}$ misleading and the concentrations may appear normal even if the individual is in fact deficient.[5] For these reasons, the intermediate form of vitamin $\mathrm{D}, 25(\mathrm{OH}) \mathrm{D}$, is being measured in my research.

Correspondence: Dr. Karthika. M, Assistant Professor, Department of Physiology, Saveetha Medical College, Thandalam, Chennai, India. E-Mail: mkarthikambbs@gmail.com 


\section{Materials and Methods}

A cross-sectional study was conducted in the Department of Physiology in collaboration with the Department of Physical Medicine \& Rehabilitation, Regional Institute of Medical Sciences (RIMS), Imphal from October 2014 to September 2016. 100 Healthy adult males in Manipur in the age group 18-35years and $\geq 50$ years were included in the study after obtaining Ethical approval from the Research Ethics Board, RIMS, Imphal.

Patients with chronic disorders were excluded from the study.

\section{Methdology:}

The serum 25-OH vitamin D level was estimated by using an enzyme immunoassay (EIA) kit (IDS immune diagnostic systems, United Kingdom). normal if it was $\geq 30 \mathrm{ng} / \mathrm{mL}(\geq 75 \mathrm{nmol} / \mathrm{L})$, insufficient if it was between 20 and $30 \mathrm{ng} / \mathrm{mL}$ ( 50 and $75 \mathrm{nmol} / \mathrm{L}$ ), and deficient if it was $<20 \mathrm{ng} / \mathrm{mL}(<50 \mathrm{nmol} / \mathrm{L})$

The BMD of the lumbar spine was determined using enCORE - based X-ray bone densitometer (Lunar Prodigy advance, GE Medical Systems, USA), which is based on the DEXA scan. AP spine measurement and analysis provides an estimation of BMD for the lumbar spine. Based on WHO classification for diagnosis of osteoporosis using BMD measurements, each group was classified into three types: normal if T-score is -1 SD and above, osteopenia if T-score is in between -1.0 SD and 2.5 SD, and osteoporosis if T-score is $-2.5 \mathrm{SD}$ and below.

Statistical Analysis: After collection, data were checked for consistency and competency and completeness. Then the data was entered in database Statistical Package for the Social Sciences (SPSS) software version 21. Statistical analysis of the data was done using descriptive statistics, mean and standard deviation were obtained. Pie chart diagram was used to show the status of Vitamin D and bone mineral density among both the age groups. Scattered plot graph was also used to plot the relationship between the variables. P-value $<0.05$ was taken as significant.

\section{Results}

The study was conducted among 100 subjects and they were divided into two groups $(18-35 \mathrm{yrs})$ and $\geq 50 \mathrm{yrs}$ depending on their age with 50 subjects in each group.

Table 1: Classification of subjects with normal 25(OH) D based on T-score

\begin{tabular}{llll}
\hline $\begin{array}{l}\text { Number of } \\
\text { subjects }\end{array}$ & $\begin{array}{l}\text { Normal } \\
\mathbf{n}(\%)\end{array}$ & $\begin{array}{l}\text { Osteopenia } \\
\mathbf{N}(\%)\end{array}$ & $\begin{array}{l}\text { Osteoporosis } \\
\mathbf{N}\end{array}$ \\
\hline 32 & 29 & 3 & 0 \\
$(20-35 \mathrm{yrs})$ & $(90.6)$ & $(9.4)$ & \\
20 & 13 & 7 & 0 \\
$(\geq 50 \mathrm{yrs})$ & $(65)$ & $(35)$ & \\
52 & 42 & 10 & \\
\hline
\end{tabular}

Table 1 shows that only $3(9.4 \%)$ of the younger age group (18-35years) and $7(35 \%)$ of the older age group ( $\geq 50$ years) were osteopenic among all subjects with normal $25(\mathrm{OH}) \mathrm{D}$ levels, whereas the rest had normal BMD levels.
Table 2: Classification of subjects with insufficiency $25(\mathrm{OH}) \mathrm{D}$ based on T-score

\begin{tabular}{llll}
\hline $\begin{array}{l}\text { Number of } \\
\text { subjects }\end{array}$ & $\begin{array}{l}\text { Normal } \\
\mathbf{n}(\%)\end{array}$ & $\begin{array}{l}\text { Osteopenia } \\
\mathbf{n}(\%)\end{array}$ & $\begin{array}{l}\text { Osteoporosis } \\
\mathbf{n}(\%)\end{array}$ \\
\hline 15 & 1 & 13 & 1 \\
$(20-35 \mathrm{yrs})$ & $(6.7)$ & $(86.7)$ & $(6.7)$ \\
22 & 0 & 10 & 12 \\
$(\geq 50 \mathrm{yrs})$ & & $(45.5)$ & $(54.5)$ \\
37 & 1 & 23 & 13 \\
\hline
\end{tabular}

Table 2 shows the levels of BMD among the subjects with $25(\mathrm{OH}) \mathrm{D}$ insufficiency. It was found that 13 $(86.7 \%)$ and $1(6.7 \%)$ subjects were osteopenic and osteoporotic, respectively, in the younger age group (1835 years). But, all the men in the older age group $(\geq 50$ years) were having low bone mass where $10(45.5 \%)$ and $12(54.5 \%)$ subjects were having osteopenia and osteoporosis, respectively.

Table 3: Classification of subjects with deficiency 25 (OH) D based on T-score

\begin{tabular}{llll}
\hline $\begin{array}{l}\text { Number } \\
\text { of } \\
\text { subjects }\end{array}$ & $\begin{array}{l}\text { Normal } \\
\mathbf{N}\end{array}$ & $\begin{array}{l}\text { Osteopenia } \\
\mathbf{n}(\%)\end{array}$ & $\begin{array}{l}\text { Osteoporosis } \\
\mathbf{n}(\%)\end{array}$ \\
\hline$(20-35 \mathrm{yrs})$ & 0 & $1(33.3)$ & $2(66.7)$ \\
$(\geq 50 \mathrm{yrs})$ & 0 & $0(0)$ & $8(100)$ \\
11 & 0 & 1 & 10 \\
\hline
\end{tabular}

Table 3 shows that none of the men in both groups (20-35 years or $\geq 50$ years) had normal BMD. The majority of the subjects had BMD readings consistent with osteoporosis that is $2(66.7 \%)$ and $8(100 \%)$ subjects in age groups of $18-35$ years and $\geq 50$ years, respectively.

Table 4 shows the status of vitamin D levels among the age group 18-35 years and $\geq 50$ years.

\begin{tabular}{llll}
\hline Age Group & Normal & $\begin{array}{l}\text { Insufficient } \\
\text { Level }\end{array}$ & Deficient \\
\hline $18-35$ years & $32(64 \%)$ & $15(30 \%)$ & $3(6 \%)$ \\
$\geq 50$ years & $20(40 \%)$ & $22(44 \%)$ & $8(16 \%)$ \\
\hline
\end{tabular}

Among the younger age group of $18-35$ years, $15(30 \%)$ were having an insufficient level, and only $3(6 \%)$ were deficient whereas in the older age group of $\geq 50 \mathrm{yrs}, 22$ $(44 \%)$ subjects had insufficient levels, and $8(16 \%)$ subjects were having deficient levels.

Table 5 shows the BMD status according to WHO $T$-score classification in the age group 18-35years and $\geq 50$ years.

\begin{tabular}{llll}
\hline Age Group & Normal & $\begin{array}{l}\text { Insufficient } \\
\text { Level }\end{array}$ & Osteoporosis \\
\hline $18-35$ years & $30(60 \%)$ & $17(34 \%)$ & $3(6 \%)$ \\
$\geq 50$ years & $13(26 \%)$ & $17(34 \%)$ & $20(40 \%)$ \\
\hline
\end{tabular}

Among the younger age group of 18-35 years, only 3 $(6 \%)$ subjects had osteoporosis, and 17 (34\%) were having osteopenia, while the rest were normal whereas in the age group $\geq 50$ years $20(40 \%)$ of the subjects had osteoporosis, and 17 (34\%) were osteopenic and only 13 $(26 \%)$ were normal. 


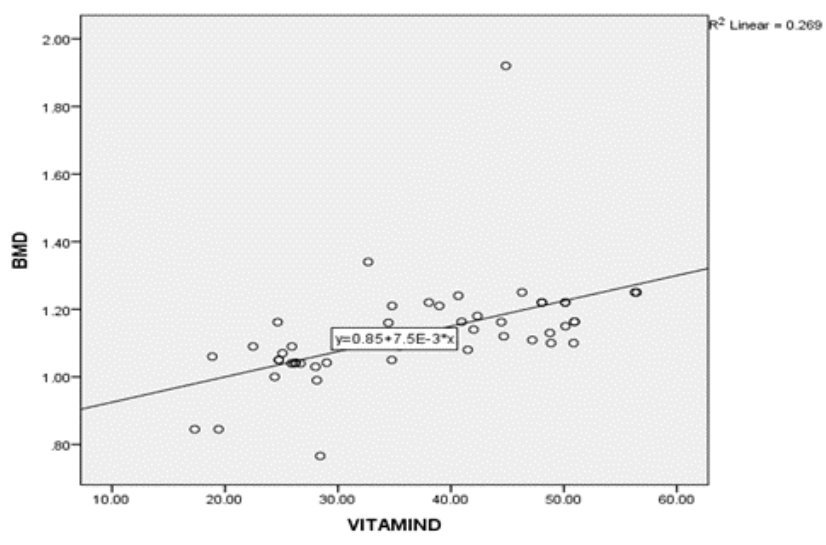

Correlation coefficient $=0.518$

\section{Fig.1: Scatter plot graph showing the correlation between $25(\mathrm{OH}) \mathrm{D} \& \mathrm{BMD}$ among age group (20-35yrs)}

Fig. 1 shows a positive correlation between vitamin $\mathrm{D}$ and BMD among the age group of $18-35$ years, where the correlation coefficient and R2 Linear were 0.518 and 0.269 respectively

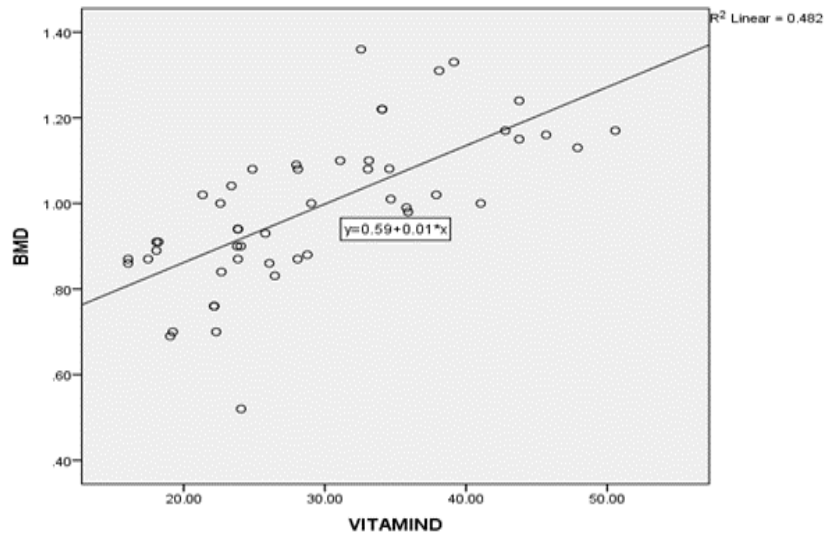

Correlation coefficient $=0.694$

Fig.2: Scatter plot graph showing the correlation between $25(\mathrm{OH}) \mathrm{D} \& \mathrm{BMD}$ among age group $(\geq 50 \mathrm{yrs})$

Fig.2 reveals a positive correlation among the older age group $\geq 50$ years with correlation coefficient and R2 Linear were 0.694 and 0.482 respectively

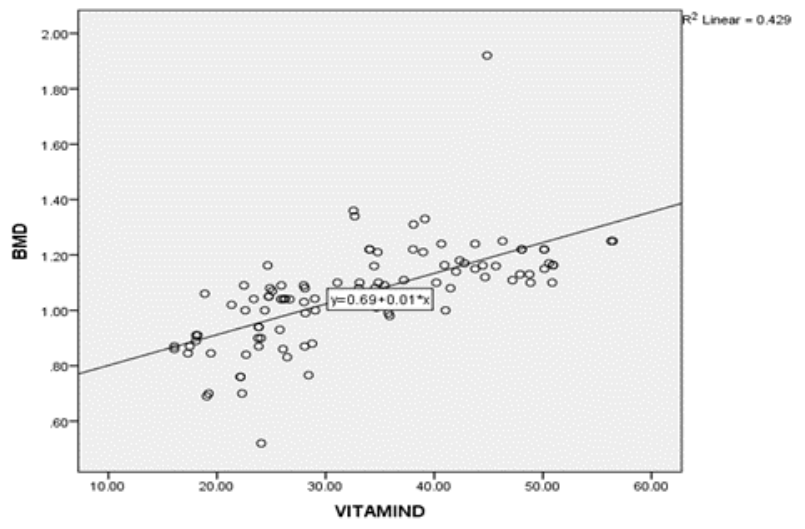

Correlation coefficient $=0.655$

Fig.3: Scatter plot graph showing a correlation between $25(\mathrm{OH}) \mathrm{D} \&$ BMD among total subjects
Fig. 3 shows the correlation between vitamin D and BMD among all the subjects as a group, which was also positively correlated with the values of correlation coefficient and R2 Linear were 0.655 and 0.429, respectively.

\section{Discussion}

The present study revealed that the majority of subjects with insufficiency of $25(\mathrm{OH}) \mathrm{D}$ had low bone mass, whereas all the subjects with $25(\mathrm{OH}) \mathrm{D}$ deficiency had BMD readings consistent with osteopenia or osteoporosis in both the age groups. This study also showed a positive correlation between BMD and 25(OH)D in most subjects, particularly in the groups with insufficiency or deficiency of $25(\mathrm{OH}) \mathrm{D}$. When the correlation between serum 25 $(\mathrm{OH}) \mathrm{D}$ levels and BMD values are considered, there are controversial and varied results among various studies found in the literature. Arya et al6 reported a significant correlation between serum 25(OH)D levels and BMD values at proximal femur among the subjects, where they concluded that subclinical $25(\mathrm{OH}) \mathrm{D}$ deficiency has an adverse effect on bone mass and therefore is linked with low BMD in those subjects. The initial results of the study by Bischoff-Ferrari et al.7 showed a strong positive relationship between $25(\mathrm{OH}) \mathrm{D}$ and $\mathrm{BMD}$ among white young and older males.

The present research demonstrated a significant strong positive correlation between 25(OH)D levels and BMD values at the studied site among both the age groups. However, no such association has been found in other studies.8,9,10 This can be partially explained by differences in population, age group, and the difference in the sites of the body studied due to different composition of trabecular and cortical bone tissue. For example, Garnero et al. 11 and Allaliet al.12 failed to show any significant correlation between 25(OH)D levels and BMD after adjusting for age. However, Rassouliet al13 found a positive correlation with spine BMD, but not with hip BMD.

Osteoporosis in men occurs from a com-plex interplay of different factors, including age-related sex hormone deficiency, genetics, and life-style choices (e.g., physical inactivity, tobacco and exces-sive alcohol use), as well as specific risk factors (e.g., corticosteroid excess) that cause bone loss and microar-chitectural disruption. On the basis of our findings, we emphasize that it is important to measure $25(\mathrm{OH}) \mathrm{D}$ levels in patients with low bone mass, rather than relying on BMD alone.

Limitation of the study: One limitation of the study is that only a single measurement of vitamin $\mathrm{D}$ was done and apart from the analysis of bone mineral density from the lumbar spine by DEXA scan no other bone markers were measured. Also, other factors such as duration of exposure to sunlight, sex hormone level, level of physical activity and lifestyle were not studied.

\section{Conclusion}

The study revealed that there was a higher prevalence of hypovitaminosis D status among older men compared to the younger age group in Manipur. This study also showed a positive correlation between vitamin D levels 
and bone mineral density in healthy adults and that there is a decreased risk for osteoporosis in ageing men with optimal 25(OH)D.

\section{Source of funding: Self}

\section{Conflict of Interest: Nil}

Acknowledgment: We acknowledge gr:t help received from the scholars whose articles are cited and included in the references of this manuscript.

\section{References}

[1] Whiting SJ, Langlois KA, Vatanparast H, GreeneFinestone LS. The vitamin D status of Canadians relative to the 2011 Dietary Reference Intakes: an examination in children and adults with and without supplement use. Am J Clin Nutr. 2011;94:128-35.

[2] Bringhurst FR, Demay MB, Kronenberg HM. Hormones and disorders of mineral metabolism. In: Kronenberg HM, Melmed S, Polonsky KS, Larsen PR, editors. Williams textbook of endocrinology. 12th ed. UK: Elsevier, 2011. p.1252-53.

[3] Shetty S, Kapoor N, Naik D, Asha HS, Prabu S, Thomas N, et al. Osteoporosis in healthy South Indian males and the influence of life style factors and Vitamin d status on bone mineral density. J Osteoporos 2014;2014:723238.

[4] Zerwerkh J.E. Blood biomarkers of vitamin D status. Am. J. Clin. Nutr., 2008, 87, 1087S-91S.

[5] Chapuy M-C, Preziosi P, Maamer M, Arnaud S, Galan P, Hercberg S, et al. Prevalence of vitamin D insufficiency in an adult normal population. Osteoporos Int. 1997;7(5):439-43.
[6] Pekkinen M, Viljakainen H, Saarnio E, LambergAllardt C, Mäkitie O. Vitamin D is a major determinant of bone mineral density at school age. 2012 Jul 2: PLoS One. 7: e40090.

[7] Bischoff-Ferrari HA, Dietrich T, Orav EJ, DawsonHughes B. Positive association between 25-hydroxy vitamin D levels and bone mineral density: a population-based study of younger and older adults. Am J Med 2004;116:634-39.

[8] Omdahl JL, Garry PJ, Hunsaker LA, Hunt WC, Goodwin JS. Nutritional status in a healthy elderly population: vitamin D. Am J Clin Nutr 1982 Dec; 36:1225-1233

[9] Hosseinpanah, F., M. Rambod, A. Hossein-Nejad, B. Larijani and F. Azizi, 2008. Association between vitamin $\mathrm{D}$ and bone mineral density in Iranian postmenopausal women. J. Bone Miner. Metab., 26: 86-92.

[10] Akhter N, Sinnott B, Mahmood K, Rao S, Kukreja $\mathrm{S}$, Barengolts E. Effects of vitamin D insufficiency on bone mineral density in African American men. Osteoporos Int. 2009;20:745-750.

[11] Garnero P, Munoz F, Sornay-Rendu E, et al. Associations of vitamin D status with bone mineral density, bone turnover, bone loss and fracture risk in healthy postmenopausal women. The OFELY study. 2007;40(3):716-722.

[12] Allali F1, El Aichaoui S, Khazani H, Benyahia B, Saoud B, El Kabbaj S et al High prevalence of hypovitaminosis $\mathrm{D}$ in Morocco: relationship to lifestyle, physical performance, bone markers, and bone mineral density. Semin Arthritis Rheum. 2009 Jun;38(6):444-51.

[13] Rassouli A, Milanian I, Moslemi-Zadeh M. Determination of serum 25-hydroxyvitamin D3 levels in early postmenopausal Iranian women: relationship with bone mineral density. Bone 2001;29(5):428-30. 